\section{OPEN ACCESS}

Edited by:

Wendy W. J. Unger, Erasmus MC-Sophia Children's

Hospital, Netherlands

Reviewed by:

Megan K. L. MacLeod, University of Glasgow,

United Kingdom

Pam Kozlowski,

Louisiana State University,

United States

${ }^{*}$ Correspondence:

Wendy A. Burgers

wendy.burgers@uct.ac.za

Rubina Bunjun

rubina.bunjun@uct.ac.za

Specialty section: This article was submitted to

Mucosal Immunity,

a section of the journal

Frontiers in Immunology

Received: 09 May 2021 Accepted: 17 June 2021

Published: 30 June 2021

Citation:

Bunjun R, Soares AP, Thawer N,

Müller TL, Kiravu A, Ginbot $Z$,

Corleis B, Murugan BD, Kwon DS,

von Groote-Bidlingmaier $F$,

Riou C, Wilkinson RJ, Walzl G and

Burgers WA (2021) Dysregulation of

the Immune Environment in the

Airways During HIV Infection.

Front. Immunol. 12:707355.

doi: 10.3389/fimmu.2021.707355

\title{
Dysregulation of the Immune Environment in the Airways During HIV Infection
}

\author{
Rubina Bunjun ${ }^{1,2 *}$, Andreia P. Soares ${ }^{1,2}$, Narjis Thawer ${ }^{1,2}$, Tracey L. Müller ${ }^{1,2}$, \\ Agano Kiravu ${ }^{1,2}$, Zekarias Ginbot ${ }^{1,2}$, Björn Corleis ${ }^{3,4}$, Brandon D. Murugan ${ }^{1,5}$, \\ Douglas S. Kwon ${ }^{3,6}$, Florian von Groote-Bidlingmaier ${ }^{7}$, Catherine Riou ${ }^{1,2,8}$, \\ Robert J. Wilkinson ${ }^{1,8,9,10}$, Gerhard Walzl ${ }^{11}$ and Wendy A. Burgers ${ }^{1,2 *}$
}

1 Institute of Infectious Disease and Molecular Medicine, University of Cape Town, Cape Town, South Africa, ${ }^{2}$ Division of Medical Virology, Department of Pathology, University of Cape Town, Cape Town, South Africa, ${ }^{3}$ Ragon Institute of MGH, MIT and Harvard, Cambridge, MA, United States, ${ }^{4}$ Institute of Immunology, Friedrich-Loeffler-Institut, Greifswald-Insel Riems, Germany, ${ }^{5}$ Division of Chemical and Systems Biology, Department of Integrative Biomedical Sciences, University of Cape Town, Cape Town, South Africa, ${ }^{6}$ Division of Infectious Diseases, Massachusetts General Hospital, Boston, MA, United States, ${ }^{7}$ Division of Pulmonology, Faculty of Medicine and Health Sciences, Stellenbosch University, Stellenbosch, South Africa, ${ }^{8}$ Wellcome Centre for Infectious Diseases Research in Africa, University of Cape Town, Cape Town, South Africa, 9 The Francis Crick Institute, London, United Kingdom, ${ }^{10}$ Department of Infectious Disease, Imperial College London, London, United Kingdom, ${ }^{11}$ DSI-NRF Centre of Excellence for Biomedical Tuberculosis Research, South African Medical Research Council Centre for Tuberculosis Research, Division of Molecular Biology and Human Genetics, Faculty of Medicine and Health Sciences, Stellenbosch University, Cape Town, South Africa

HIV-1 increases susceptibility to pulmonary infection and disease, suggesting pathogenesis in the lung. However, the lung immune environment during HIV infection remains poorly characterized. This study examined $T$ cell activation and the cytokine milieu in paired bronchoalveolar lavage (BAL) and blood from 36 HIV-uninfected and 32 HIVinfected participants. Concentrations of 27 cytokines were measured by Luminex, and $T$ cells were phenotyped by flow cytometry. Blood and BAL had distinct cytokine profiles $(p=0.001)$. In plasma, concentrations of inflammatory cytokines like IFN- $\gamma(p=0.004)$ and TNF- $\alpha(p=0.004)$ were elevated during HIV infection, as expected. Conversely, BAL cytokine concentrations were similar in HIV-infected and uninfected individuals, despite high BAL viral loads (VL; median 48,000 copies/ml epithelial lining fluid). HIV-infected individuals had greater numbers of $T$ cells in BAL compared to uninfected individuals $(p=0.007)$; and BAL VL positively associated with CD4+ and CD8+ $T$ cell numbers $(p=0.006$ and $p=0.0002$, respectively) and $C X C L 10$ concentrations $(p=0.02)$. BAL $T$ cells were highly activated in HIV-infected individuals, with nearly 2-3 fold greater frequencies of CD4+CD38+ (1.8-fold; $p=0.007), C D 4+C D 38+H L A-D R+$ (1.9-fold; $p=0.0006), C D 8+C D 38+$ (2.8-fold; $p=0.0006), C D 8+H L A-D R+(2$-fold; $p=0.022$ ) and CD8+CD38+HLA-DR+ (3.6-fold; $\mathrm{p}<0.0001$ ) cells compared to HIV-uninfected individuals. Overall, this study demonstrates a clear disruption of the pulmonary immune environment during HIV infection, with readily detectable virus and activated $T$ lymphocytes, which may be driven to accumulate by local chemokines.

Keywords: lung, HIV, activation, T cells, inflammation, cytokines 


\section{INTRODUCTION}

Sub-Saharan Africa has 25.6 million people currently living with HIV and 970,000 new infections a year (1). HIV-infected individuals are highly susceptible to both infectious and noncommunicable pulmonary diseases such as tuberculosis [TB], Pneumocystis pneumonia, chronic obstructive lung disease [COPD] or pulmonary fibrosis (2-4). Although antiretroviral treatment (ART) has reduced the overall prevalence of HIVassociated lung disease, respiratory diseases still contribute to substantial morbidity and mortality in the HIV-infected population (5-7). This suggests that HIV pathogenesis extends to the lungs, requiring additional strategies to reduce the burden of respiratory diseases in HIV-infected individuals.

HIV infection is characterized by systemic immune hyperactivation and profound damage to mucosal compartments due to viral replication (8-16). Consequently, the demonstrated burden of HIV in the lung has significant implications for local pathology and impaired immunity to respiratory pathogens (1723). HIV-associated lymphocytic alveolitis, the infiltration of lymphocytes into the airways, is associated with local viral replication (24-28). However, due to the difficulty in studying and sampling the lung compartment, the full extent of HIVassociated pulmonary immune dysfunction is not well understood.

Our previous work established that early HIV infection had a limited effect on Mycobacterium tuberculosis (M.tb)-specific T cell responses in BAL (29), warranting a broader investigation of the immune milieu of the lung. Therefore, in this study, we examined viral burden, $\mathrm{T}$ cell activation and cytokine concentrations in paired BAL and blood from HIV-uninfected and HIV-infected participants.

\section{METHODS}

\section{Study Participants}

Participants were recruited from Cape Town, South Africa and grouped according to their HIV status: 32 ART-naive HIVseropositive persons with CD4+ T-cell counts of $>400$ cells $/ \mathrm{mm}^{3}$ and $36 \mathrm{HIV}$-seronegative persons. Participants were not eligible for this study if they had any active respiratory infections. Active TB was excluded on the basis of symptoms, radiological evidence, and BAL fluid culture results. All participants had latent TB infection (LTBI) as confirmed by a positive IFN- $\gamma$ release assay (IGRA; Quantiferon-TB Gold, Qiagen, Hilden, Germany). This study was approved by the Research Ethics Committees of the University of Cape Town (REF158/2010) and Stellenbosch University (N10/08/275). All participants provided written, informed consent.

\section{Collection and Processing of Samples}

BAL samples were collected and processed as previously described (29). Briefly, $160 \mathrm{ml}$ of saline was instilled in the middle lobe bronchus and aspirated. After centrifugation, acellular BAL fluid (BALF) was stored at $-80^{\circ} \mathrm{C}$ and the cell pellet was washed and filtered through a $100-\mu \mathrm{m}$ cell strainer
(CellTrics, Partec, Münster, Germany). Cells were then counted using Trypan Blue exclusion and differentially stained in order to count macrophages, lymphocytes and neutrophils (RapidDiff, Clinical Sciences Diagnostics, Johannesburg, South Africa). The absolute number of T lymphocytes in BAL fluid was calculated using differential staining and microscopy, and the frequencies of live $\mathrm{CD} 3+, \mathrm{CD} 4+$, or $\mathrm{CD} 8+\mathrm{T}$ cells from a flow cytometry phenotyping panel (see below). To correct for epithelial lining fluid (ELF) dilution due to variable fluid volumes recovered, the urea method was used (QuantiChrom, Clonagen, Brussels, Belgium) as described elsewhere (30). BALF viral loads and BAL cell counts were standardized according to the volume of ELF sampled (median, $1 \mathrm{~mL}$; IQR, $0.75-1.64 \mathrm{~mL}$ ) and are expressed as the number of cells or viral load per ml of ELF.

Blood specimens were collected and processed within 4 hours. Heparinized whole blood was treated with red blood cell lysis buffer without a fixative, and the cell pellet was immediately stained with a panel of antibodies for phenotyping by flow cytometry.

\section{Phenotyping by Multiparameter Flow Cytometry}

The staining panel consisted of CCR5 PE (2D7), CD38 APC (HIT2), CD3 PE-Cy7 (SK7), HLA-DR APC-Cy7 (L243; all from BD Biosciences, New Jersey, USA), CD4 PE-Cy5.5 (S3.5), CD8 Qdot-705 (3B5), CD19 Pacific Blue (SJ25-CI), CD14 Pacific Blue (T̈k4; all from Invitrogen, California, USA), CD45RO ECD (UCHL1), CD27 PE-Cy5 (1A4CD27; both from Beckman Coulter, California, USA). Blood and BAL cells were stained with a viability marker (violet fixable viability dye, Invitrogen), followed by CCR5 labelling at $37^{\circ} \mathrm{C}$ before labelling with antibodies against surface markers. Cells were fixed in $1 \mathrm{x}$ CellFix (BD Biosciences) for acquisition a BD Fortessa using FACSDiva software. Data were analysed using FlowJo (TreeStar, Oregon, USA). Gates were set using fluorescence-minus-one (FMO) controls.

\section{Measurement of Soluble Analytes}

A total of 27 cytokines and chemokines were measured in paired plasma and concentrated BALF samples using human magnetic bead multiplex kits (Merck Millipore, Massachusetts, USA). The Human Th17 magnetic bead kit was used to measure IL-1 $\beta$, IL-4, IL-6, IL-10, IL-13, IFN- $\gamma$, GM-CSF, TNF- $\alpha$, IL-21, IL-22, IL-23, IL-15, IL-17 and CCL20. The Human Cytokine/Chemokine magnetic bead kit was used to measure EGF, IL-12p70, IL-7, CXCL8 (IL-8), CXCL10 (IP-10), CCL2 (MCP-1), CCL3 (MIP$1 \beta)$, CCL4 (MIP-1 $\alpha$ ), CCL5 (RANTES), CCL7 (MCP-3), CCL11 (eotaxin), CX3CL1 (fractalkine) and SCD40L. Samples were run in duplicate and the mean was calculated. Cytokine concentrations were adjusted for BAL fluid concentration factor. Cytokines that fell below the limit of detection were reported as half the minimum detectable concentration. Analytes were excluded if they fell below the empirical cut-off (either undetectable in $50 \%$ or more participants, or with a median of less than twice the minimum detectable concentration for that analyte). These were GM-CSF, IL-22, IL-4, IFN- $\gamma$, CCL11 
in BAL; and GM-CSF, IL-15, IL-1ß, IL-22, IL-4, IL-6 in blood. Analytes were categorized as pro-inflammatory (IL-1 $\beta$, IL-6, IL12p70, IL-23, TNF- $\alpha$, sCD40L), adaptive (IFN- $\gamma$, IL-13, IL-17), $\gamma$-chain cytokines (IL-7, IL-15, IL-21), regulatory (IL-10), growth factors (EGF) and chemokines (CCL2, CCL3, CCL4, CCL5, CCL7, CCL11, CCL20, CXCL8, CXCL10, CX3CL1) based on function. The relative proportion of each analyte was calculated as a percentage of the sum total of the analyte concentrations in that compartment.

\section{Statistical Analyses}

Non-parametric statistical analyses (Mann-Whitney $U$ test, the Wilcoxon matched pairs test, and the Spearman rank test) were performed using Prism 7 (GraphPad). Unsupervised hierarchical clustering, principal component analyses (PCA) and permANOVA were carried out in $\mathrm{R}$ (31) using the following packages: pheatmap (32), vegan (33), ggfortify (34), RColourBrewer (35). False discovery rate (FDR) step down procedures were performed to adjust for multiple comparisons as previously described (36). A p value of $<0.05$ was considered statistically significant. The $\mathrm{p}$ values, $\mathrm{p} \leq 0.05, \mathrm{p} \leq 0.01, \mathrm{p} \leq 0.001, \mathrm{p} \leq 0.0001$ are reported as ${ }^{*},{ }^{* *},{ }^{* *}$ and $* * * *$, respectively.

\section{RESULTS}

\section{Cohort Description}

Blood and BAL were collected from HIV-infected ( $\mathrm{n}=32$; median age, 31 years; $96 \%$ female) and uninfected $(n=36$; median age, 23 years; $60 \%$ female) participants from Cape Town, South Africa (Table 1 and Table S1). HIV-uninfected participants had a median CD4 count of 832 cells $/ \mathrm{mm}^{3}$ (IQR 741-1028 cells $/ \mathrm{mm}^{3}$ ), while the HIV-infected individuals had a median of $601 \mathrm{cells} / \mathrm{mm}^{3}$ (IQR 523-782 cells $/ \mathrm{mm}^{3} ; \mathrm{p}<0.0001$ ). HIV-infected persons were ART-naïve, however persons with CD4 counts $<400$ cells $/ \mathrm{mm}^{3}$ were excluded in order to study the impact of HIV infection prior to severe immunodeficiency. HIV-infected participants had a median HIV viral load in BAL fluid of 48,224 RNA copies/ml ELF (IQR 2,115-27,378 copies/ml ELF) and a median plasma viral load of 6,153 RNA copies $/ \mathrm{mm}^{3}$ (IQR 2,125-17,623 copies $/ \mathrm{mm}^{3}$; $\mathrm{p}=\mathrm{ns}$ ). Consistent with previous reports, there was a significant positive correlation between HIV load in BALF and plasma $(\mathrm{p}<0.0001$; $\mathrm{r}=0.696$; data not shown) $(19,21)$. These data demonstrate that despite relatively well-preserved CD4 counts, the HIV-infected group had substantial amounts of virus detectable in the airways and in blood.

TABLE 1 | Clinical characteristics of study participants.

\begin{tabular}{|c|c|c|}
\hline & HIV-uninfected $(n=36)$ & HIV-infected $(n=32)$ \\
\hline Blood CD4 count (cells $/ \mathrm{mm}^{3}$ ) & $832(741-1,028)$ & 601 (523-782) \\
\hline $\begin{array}{l}\text { Plasma viral load } \\
\text { (RNA copies/ml) }\end{array}$ & - & $6,153(2,125-17,623)$ \\
\hline $\begin{array}{l}\text { BAL viral load } \\
\text { (RNA copies/ml ELF) }\end{array}$ & - & $48,224(2,115-27,378)$ \\
\hline
\end{tabular}

Data are median (interquartile range). BAL, bronchoalveolar lavage; ELF, epithelial lining fluid.

\section{Distinct Cytokine Profiles in BAL and Blood}

To investigate the immune environment in the airways compared to peripheral blood, soluble cytokines and chemokines were measured in BAL fluid and blood plasma (Tables S2, S3). Most cytokines (22/24; 92\%) were significantly higher in plasma than BAL fluid, regardless of HIV status (Figure 1A). Consequently, principal component analysis (PCA) demonstrated a distinct separation of cytokine profiles by compartment but not HIV status $\left(\mathrm{p}=0.001, \mathrm{r}^{2}=0.508\right.$; Figure 1B). We then examined the relative proportion of each cytokine adjusted to represent $100 \%$ of the overall milieu in each compartment (Figure 1C). Again, we observed divergent cytokine profiles between compartments. In plasma, soluble CD40L was the most abundant and made up $43 \%$ of the milieu in HIV-uninfected individuals, but only contributed 3\% to the BAL cytokine profile in the same individuals. Likewise, CXCL10 contributed $44 \%$ to the milieu in BAL fluid (44\%) but only $11 \%$ in plasma. Based on these observations, we focused on examining the effect of HIV infection on the airways and blood separately to account for compartmentalisation.

\section{The Cytokine Milieu in BAL Is Less Affected by HIV Infection Than Blood}

We first investigated the soluble cytokine milieu to elucidate which immune mediators were elevated during HIV infection. In BAL fluid, there were few differences in the soluble immune milieu between study populations. Compared to uninfected individuals, $\mathrm{HIV}$-infected participants had lower concentrations of EGF ( $\mathrm{p}=0.040$, median: $2.02 \mathrm{pg} / \mathrm{ml}$ and $0.48 \mathrm{pg} / \mathrm{ml}$, respectively) and CX3CL1 ( $\mathrm{p}=0.044$, median: $4.61 \mathrm{pg} / \mathrm{ml}$ and $2.24 \mathrm{pg} / \mathrm{ml}$, respectively; Figure 2A) after correcting for multiple comparisons. Furthermore, unsupervised hierarchical clustering showed no clear clustering of cytokine profiles between HIV-infected and uninfected individuals (Figure 2B). Consistent with this, PCA demonstrated that cytokine profiles of the two groups did not visibly separate according to HIV status, although there was weak but significant variation in cytokine profiles between HIV-infected and uninfected groups ( $\mathrm{p}=0.023, \mathrm{r}^{2}=0.04$; Figure $2 \mathrm{C}$ ).

In contrast to the airways, the plasma cytokine milieu differed considerably between HIV-infected and uninfected individuals. Compared to uninfected individuals, HIV-infected individuals had notably higher concentrations of inflammatory cytokines IFN- $\gamma(\mathrm{p}=0.004$, median: $6.32 \mathrm{pg} / \mathrm{ml}$ vs $12.47 \mathrm{pg} / \mathrm{ml})$, TNF- $\alpha$ $(\mathrm{p}=0.004$, median: $10.18 \mathrm{pg} / \mathrm{ml}$ vs $25.02 \mathrm{pg} / \mathrm{ml})$ and the chemokine CXCL10 ( $\mathrm{p}=0.002$, median: $219.5 \mathrm{pg} / \mathrm{ml}$ vs 487.41 $\mathrm{pg} / \mathrm{ml}$ ), and lower concentrations of IL-7 ( $\mathrm{p}=0.036$, median: 2.21 $\mathrm{pg} / \mathrm{ml}$ vs $1.17 \mathrm{pg} / \mathrm{ml}$ ), IL-12p70 ( $\mathrm{p}=0.007$, median: $6.91 \mathrm{pg} / \mathrm{ml}$ vs $2.43 \mathrm{pg} / \mathrm{ml}$ ), EGF ( $\mathrm{p}=0.018$, median: $15.17 \mathrm{pg} / \mathrm{ml} v s 7.07 \mathrm{pg} / \mathrm{ml}$ ) and the chemokines CCL3 ( $\mathrm{p}=0.002$, median: $49.12 \mathrm{pg} / \mathrm{ml} v s 15$ $\mathrm{pg} / \mathrm{ml}), \operatorname{CCL} 4$ ( $\mathrm{p}=0.017$, median: $10.4 \mathrm{pg} / \mathrm{ml}$ vs $1.81 \mathrm{pg} / \mathrm{ml}$ ), CCL7 ( $\mathrm{p}=0.002$, median: $20.3 \mathrm{pg} / \mathrm{ml}$ vs $9.22 \mathrm{pg} / \mathrm{ml}$ ), CX3CL1 ( $\mathrm{p}=0.004$, median: $169.7 \mathrm{pg} / \mathrm{ml}$ vs $95.12 \mathrm{pg} / \mathrm{ml}$ ) and CXCL8 ( $\mathrm{p}=0.004$, median: $15.72 \mathrm{pg} / \mathrm{ml}$ vs $5.25 \mathrm{pg} / \mathrm{ml}$; Figure 3A). Indeed, plasma cytokine profiles of HIV-infected and uninfected participants displayed a degree of clustering by unsupervised 
A

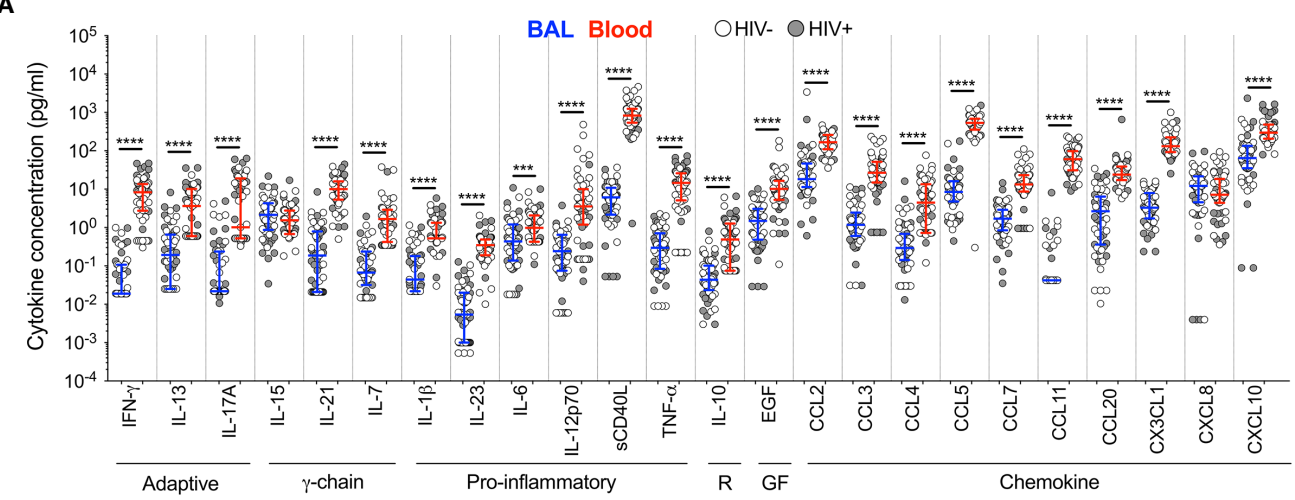

B

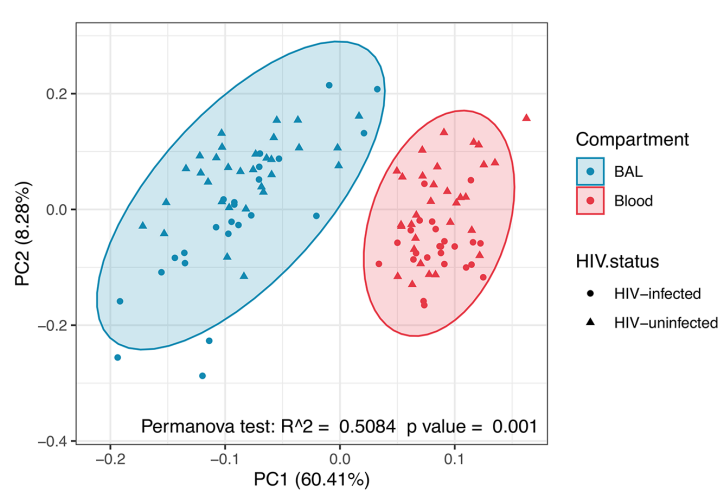

c

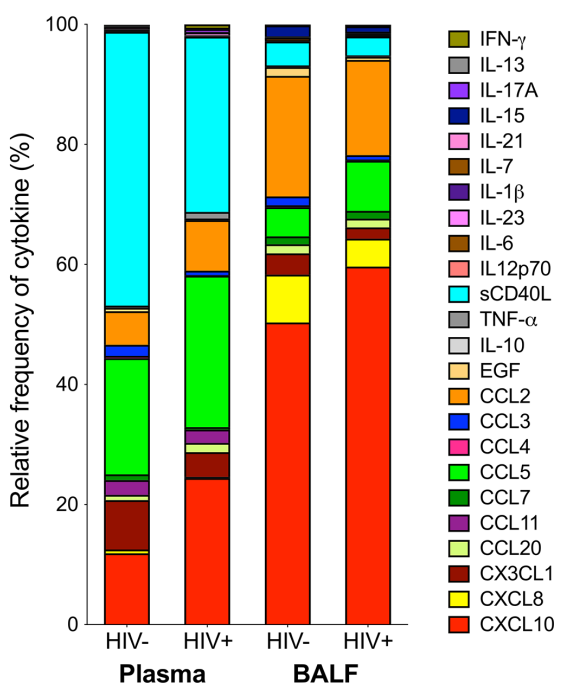

FIGURE 1 | Soluble immune mediators in blood and BAL. (A) Comparison of cytokine concentrations in BAL (blue) and blood (red) of HIV-infected (filled circles) and HIV-uninfected (open circles) individuals. "R" refers to regulatory cytokines and "GF" refers to growth factors. The blue and red lines denote the median and interquartile ranges for BAL and blood, respectively. Statistical analyses were performed using a non-parametric Wilcoxon paired test with False Discovery Rate (FDR) step down correction. (B) Principal component analysis and permutational multivariate analysis of variance (permANOVA) of cytokine concentrations in BAL (blue) and blood (red). (C) Cytokine concentration expressed as a proportion of the total milieu in BAL and plasma. The relative proportion of each analyte was calculated as a percentage of the sum total of the analyte concentrations in that compartment. GM-CSF, IL-22 and IL-4 were excluded altogether as they were below the level of detection in both BAL and blood. Analytes that fell below the limit of detection for some participants were reported as half the minimum detectable concentration. The $p$ values, $p \leq 0.05, p \leq$ $0.01, p \leq 0.001, p \leq 0.0001$ are reported as ${ }^{*},{ }^{* \star},{ }^{* \star *}$ and ${ }^{* \star * *}$, respectively.

hierarchical clustering (Figure 3B). Similarly, principal component analysis demonstrated partial separation of cytokine profiles by HIV status ( $\mathrm{p}=0.001, \mathrm{r}^{2}=0.109$; Figure $3 \mathrm{C}$ ). Overall, these results demonstrate that there were larger differences in the cytokine milieu between anatomical compartments than between HIV-infected and uninfected participants, with notably fewer differences observed within BAL compared to plasma, despite high BAL HIV load in these participants.

\section{Chemokine Concentrations Associate With T Cell Numbers and HIV Viral Load in the Airways}

As reported previously (29), we found that the absolute numbers of $\mathrm{T}$ cells from BAL were significantly higher in HIV-infected participants, and this correlated positively with BAL viral load (Figure S1). To examine the interplay between HIV, the cytokine milieu and $\mathrm{T}$ cells, we investigated the relationships between cytokine concentrations, absolute $\mathrm{T}$ cell numbers and viral load. In plasma, CXCL10 concentration was significantly positively correlated with viral load ( $\mathrm{p}=0.03, \mathrm{r}=0.444$; Figure 4A) but there was no relationship with CD4 count ( $p=n s$; Figure 4B). TNF- $\alpha$ and $s C D 40 \mathrm{~L}$ were also associated with plasma viral load $(\mathrm{p}=0.0499, \mathrm{r}=0.405)$ and CD4 count $(\mathrm{p}=0.032, \mathrm{r}=-0.439)$, respectively (data not shown). In BAL fluid, chemokines were significantly associated with viral load and $\mathrm{T}$ cell numbers. Specifically, the concentration of CXCL10 positively correlated with viral load $(\mathrm{p}=0.02, \mathrm{r}=0.471)$ and the number of $\mathrm{CD} 3+$ $(\mathrm{p}=0.001, \mathrm{r}=0.764), \mathrm{CD} 4+(\mathrm{p}=0.003, \mathrm{r}=0.729)$ and $\mathrm{CD} 8+\mathrm{T}$ 
A

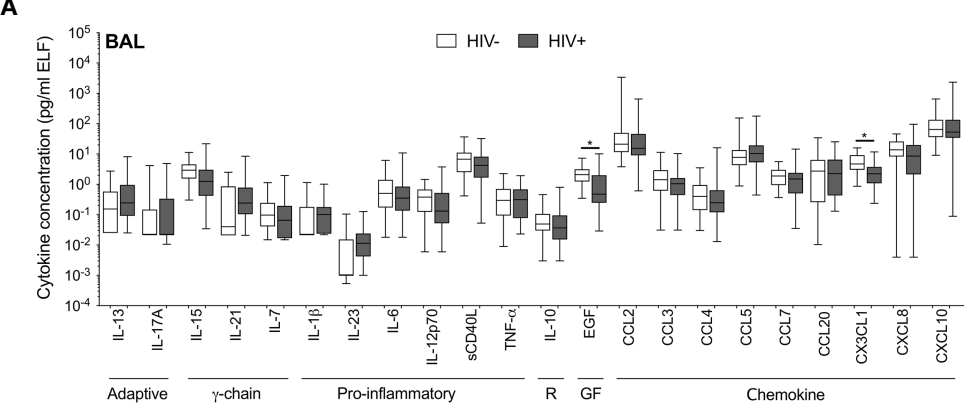

B

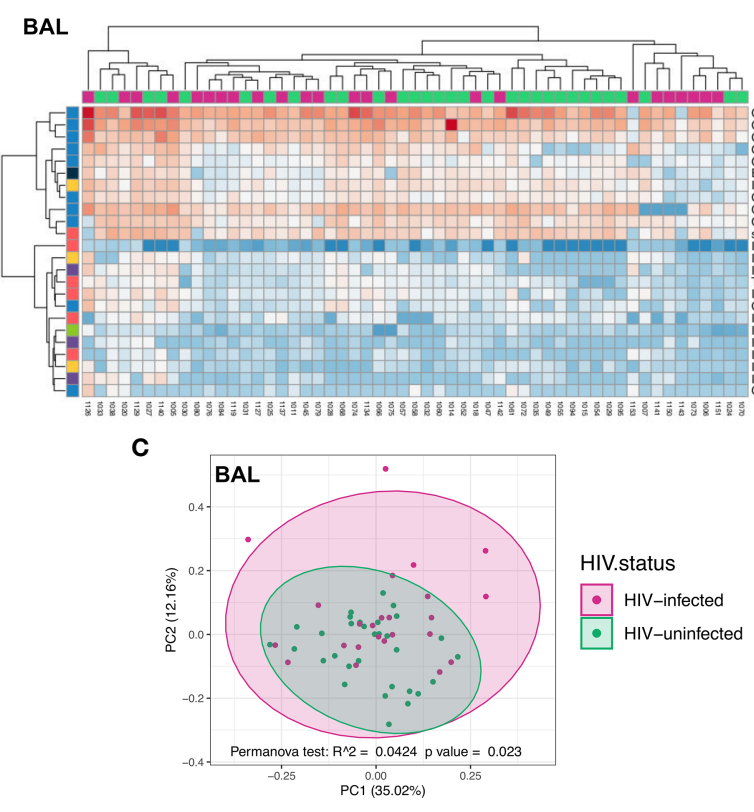

FIGURE 2 | Soluble immune mediators in BAL in HIV-infected and uninfected individuals. (A) Box and whisker plots (min-max) comparing cytokine concentrations in BAL according to HIV status. "R" refers to regulatory cytokines and "GF" refers to growth factors. Statistical analyses were performed using a non-parametric MannWhitney U test with False Discovery Rate (FDR) step down correction. (B) Unsupervised hierarchical clustering of cytokines in BAL. (C) Principal component analysis and permutational multivariate analysis of variance (permANOVA) of soluble immune mediators in HIV-infected (pink; $n=24$ ) and uninfected (green; $n=31$ ) participants. GM-CSF, IL-22, IL-4, IFN- $\gamma$ and CCL11 were excluded as they were below the level of detection. The $p$ values, $p \leq 0.05, p \leq 0.01, p \leq 0.001, p \leq 0.0001$ are reported as ${ }^{*},{ }^{\star \star},{ }^{\star \star \star}$ and ${ }^{\star \star \star \star}$, respectively.

cells $(\mathrm{p}=0.001, \mathrm{r}=0.764)$ (Figures 4C-F). To determine whether outliers drove these correlations, we excluded the two outliers with high CXCL10 concentrations. Apart from viral load $(p=0.07)$, the associations remained statistically significant after the exclusions. Additionally, CCL2 positively associated with BAL fluid viral load $(\mathrm{p}=0.0496, \mathrm{r}=0.405)$, and CXCL8 was positively associated with numbers of CD3+ $(\mathrm{p}=0.05, \mathrm{r}=0.516)$ and CD8+ ( $\mathrm{p}=0.0499, \mathrm{r}=0.516) \mathrm{T}$ cells (data not shown). These associations suggest that the presence of HIV in the airways may lead to elevated levels of chemokines, and concomitant increases in $\mathrm{T}$ cells in the alveolar space.

\section{T Cells From HIV-Infected Participants Are Highly Activated in BAL and Blood}

Although widespread immune hyperactivation is well described during HIV infection, little is known about the activation state of lymphocytes in the airways and how this compares to peripheral blood. Thus, we characterized T cell activation, as measured by CD38 and HLA-DR expression (Figure 5A and Figure S2) and found that in HIV-uninfected individuals, frequencies of activated $\mathrm{CD} 4+\mathrm{T}$ cells were higher in BAL compared to blood (for HLA-DR+ $\mathrm{p}<0.0001$, median: $22.75 \%$ vs $5.49 \%$; for CD38+HLA-DR+ $\mathrm{p}=0.0006$, median: $3.32 \%$ vs $1.22 \%$, respectively; Figure S3A). However, in HIV-infected individuals, there were no significant differences in $\mathrm{CD} 4+\mathrm{T}$ cell activation between compartments (Figure S3A). There were also no differences in activated CD8+ $\mathrm{T}$ cells between compartments (Figure S3B). We observed higher frequencies of CCR5expressing CD4+ and CD8+ T cells in BAL compared to blood, regardless of HIV status (Figure S3C). Furthermore, the frequencies of CD4+CD38+ and CD4+CD38+HLA-DR+ T cells between blood and BAL were positively correlated in both HIV-infected ( $\mathrm{p}=0.018$, $\mathrm{r}=0.537$ and $\mathrm{p}=0.033, \mathrm{r}=0.491$, respectively) and uninfected individuals $(\mathrm{p}=0.002, \mathrm{r}=0.622$ and $\mathrm{p}=0.049, \mathrm{r}=0.424$, respectively; 
A

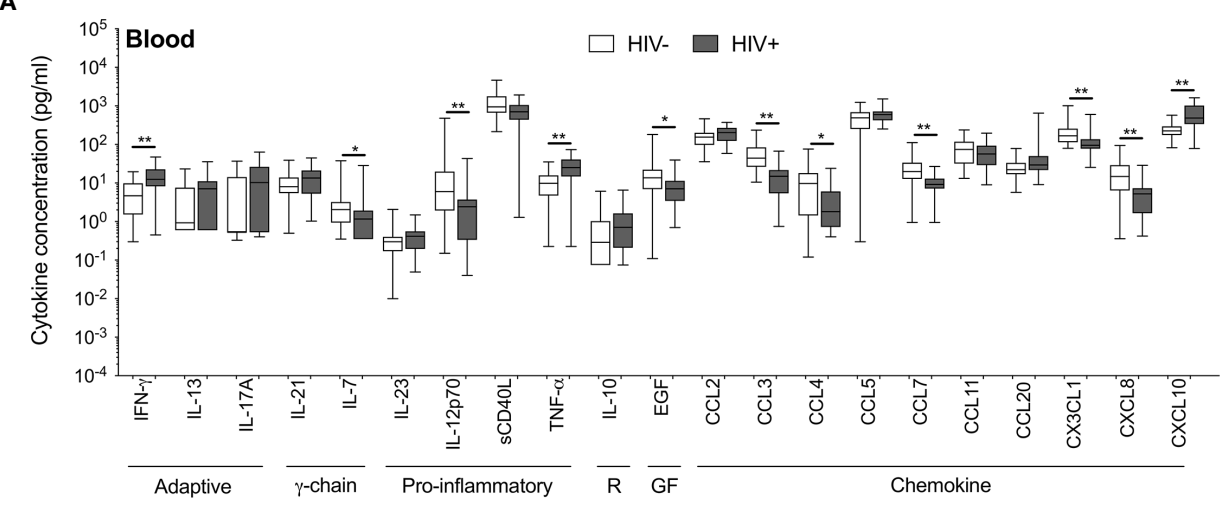

B

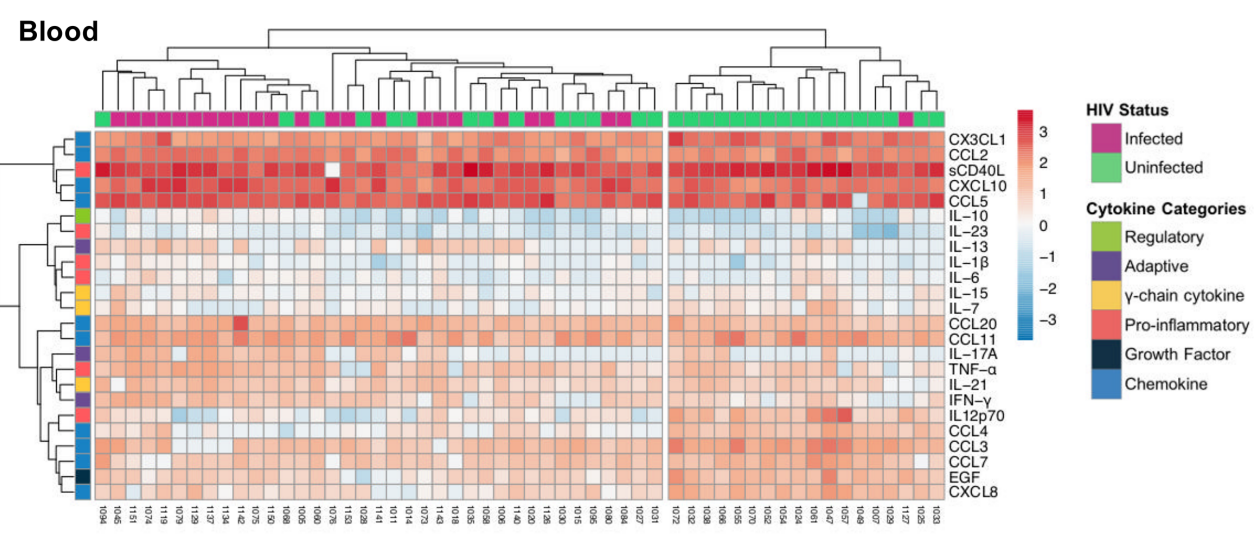

C

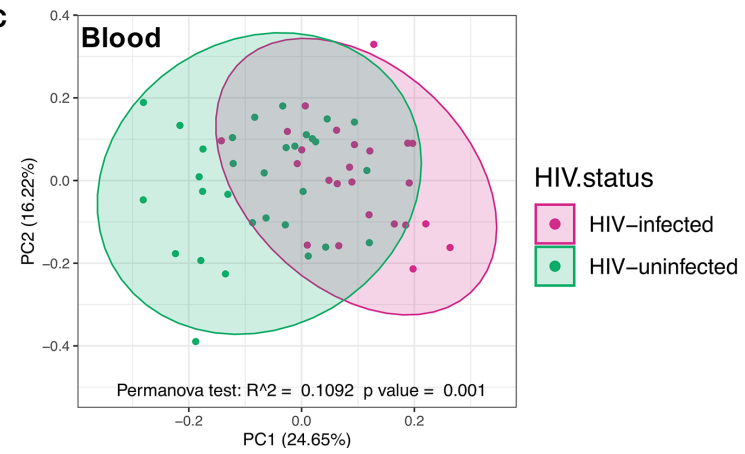

FIGURE 3 | Soluble immune mediators in blood in HIV-infected and uninfected individuals. (A) Box and whisker plots (min-max) comparing cytokine concentrations in plasma according to HIV status. "R" refers to regulatory cytokines and "GF" refers to growth factors. Statistical analyses were performed using a non-parametric Mann-Whitney U test with False Discovery Rate (FDR) step down correction. (B) Unsupervised hierarchical clustering of cytokines in blood. (C) Principal component analysis and permutational multivariate analysis of variance (permANOVA) of soluble immune mediators in HIV-infected (pink; $n=24$ ) and uninfected (green; $n=31$ ) participants. GM-CSF, IL-15, IL-1 $\beta, I L-22, I L-4$ and IL-6 were excluded as they were below the level of detection. The $p$ values, $p \leq 0.05, p \leq 0.01, p \leq 0.001, p \leq$ 0.0001 are reported as ${ }^{*},{ }^{\star \star},{ }^{\star \star \star}$ and ${ }^{* \star \star *}$, respectively.

Figure 5B and data not shown). CD8+CD38+ T cells also correlated significantly between compartments, but only in HIV-infected individuals $(\mathrm{p}=0.002, \mathrm{r}=0.762$; Figure 5C). There was no association between $\mathrm{T}$ cell activation and BAL or plasma viral load (data not shown).

Direct comparison of $\mathrm{T}$ cell activation according to $\mathrm{HIV}$ status demonstrated that compared to uninfected participants, $\mathrm{HIV}$-infected participants had higher frequencies of BAL CD4+ $\mathrm{T}$ cells expressing CD38 ( $\mathrm{p}=0.007$, medians $9.97 \%$ vs $17.8 \%$ ) and co-expressing CD38 and HLA-DR ( $\mathrm{p}=0.0006$, medians $3.16 \%$ vs $6.05 \%$; Figure 5D). Consistent with this, there were significantly higher frequencies of activated CD4+ T cells in blood of HIVinfected individuals compared to uninfected individuals ( $\mathrm{p}=0.0002$, medians $19.55 \%$ vs $11.1 \%$ for $\mathrm{CD} 4+\mathrm{CD} 38+$; $\mathrm{p}<0.0001$, medians $15.25 \%$ vs $5.36 \%$ for CD4+HLA-DR+; $\mathrm{p}<0.0001$, medians $4.29 \%$ vs $1.22 \%$ for CD4+CD38+HLA-DR+; Figure 5D). Higher CD8+ T cell activation was also demonstrated for HIV-infected individuals compared to uninfected individuals 
A

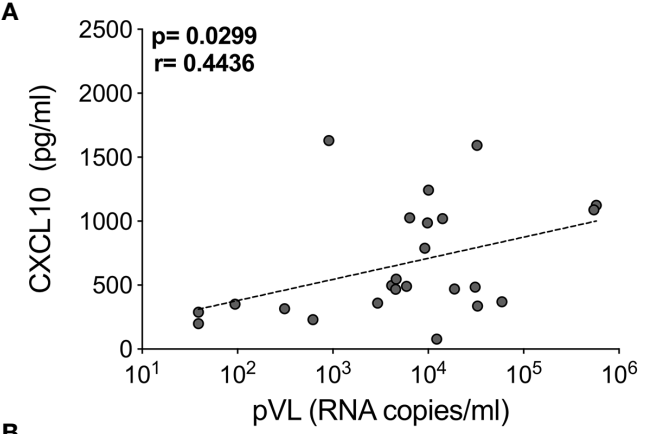

B
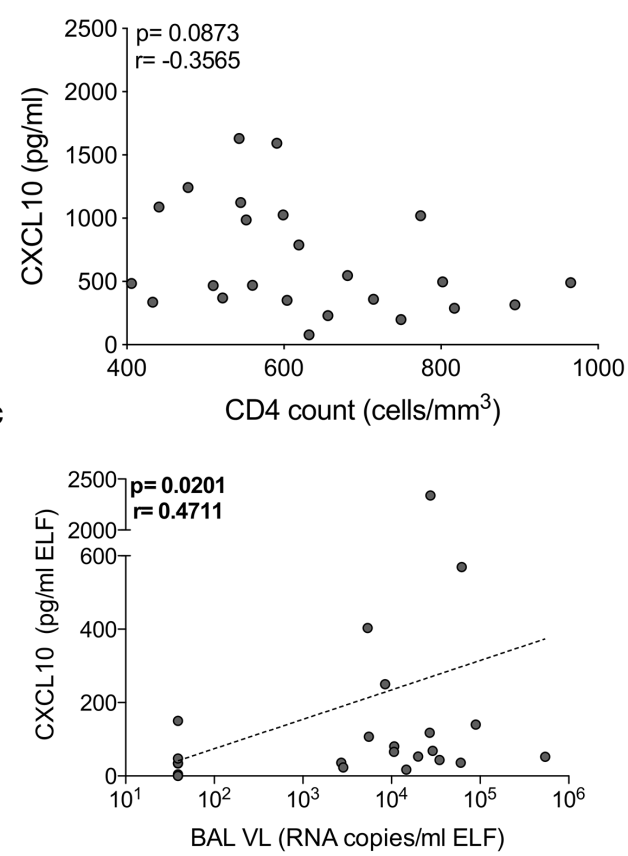

D
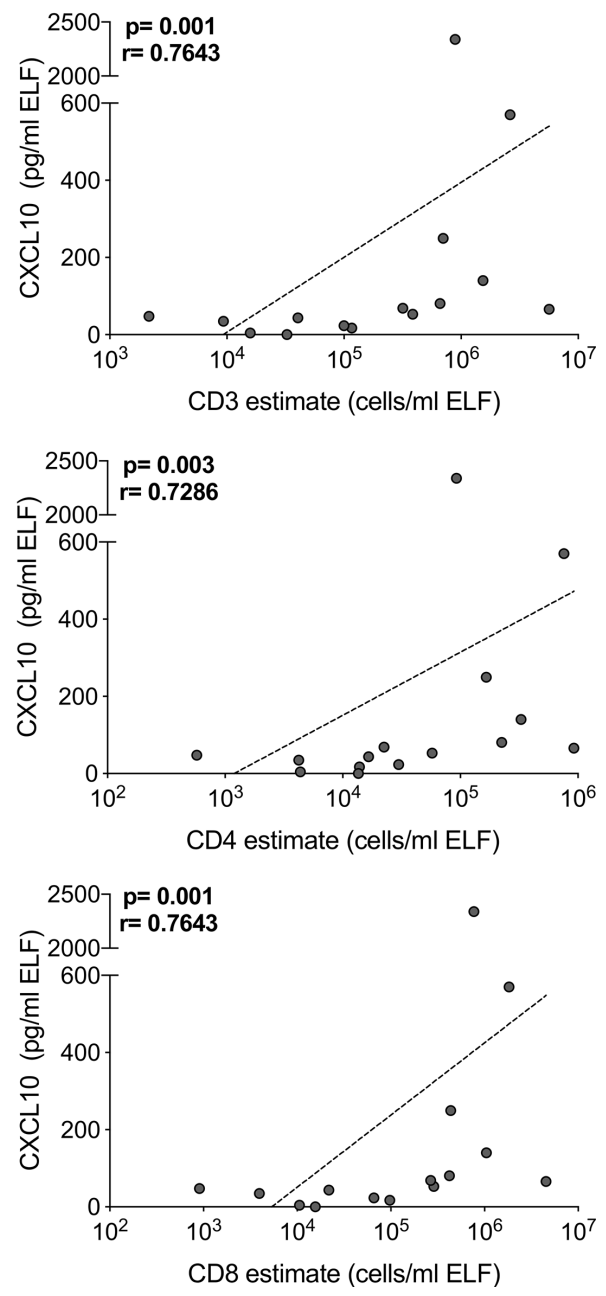

FIGURE 4 | CXCL10 correlates with HIV viral load and T cell numbers in BAL of HIV-infected individuals. The correlation between CXCL10 concentration and (A) plasma HIV viral load, (B) blood CD4 count in blood, (C) BAL HIV viral load ( $n=24)$, (D) BAL CD3, (E) CD4 and (F) CD8 T cell estimates ( $n=16)$. Each dot represents an individual. Only individuals with absolute BAL cell count data were plotted. The dotted line indicates linear regression for statistically significant correlations. Statistical analyses were performed using a non-parametric Spearman rank correlation.

in both BAL ( $\mathrm{p}=0.0007$, medians $22.9 \%$ vs $8.0 \%$, for CD8+CD38+; $\mathrm{p}=0.022$, medians $21.4 \%$ vs $10.7 \%$ for CD8+HLA-DR+; $\mathrm{p}<0.0001$, medians $6.3 \%$ vs $1.73 \%$ for CD $8+C D 38+$ HLA-DR+) and blood ( $\mathrm{p}=0.0002$, medians $21.15 \%$ vs $6.83 \%$ for CD8+CD38+; $\mathrm{p}<0.0001$, medians $21.1 \%$ vs $9.36 \%$ for CD8+HLA-DR+; $\mathrm{p}<0.0001$, medians 9.91\% vs 2.1\% for CD8+CD38+HLA-DR+; Figure 5E). These observations confirm that $\mathrm{T}$ cell activation was consistently higher in HIV-infected individuals in both BAL and blood.

\section{Limited Influence of BAL Cytokines on T Cell Activation}

The relationships between cytokines and $\mathrm{T}$ cell activation in BAL was examined next. Figure 6 shows the Spearman rho (r) of each correlation between cytokines and T cells expressing CD38, HLADR or CCR5. Overall, more associations between cytokines and activated $\mathrm{T}$ cells were observed in HIV-uninfected individuals compared to HIV-infected individuals, which could suggest some regulatory disruptions during HIV infection. However, no significant associations remained after adjusting for multiple comparisons, and linear regression analysis revealed no associations between $\mathrm{T}$ cell activation and cytokine concentrations (data not shown).

\section{DISCUSSION}

This study investigated HIV-associated immune changes in the airways, to better understand the high incidence of lung disease during HIV infection. We found distinct compartmentalisation of cytokines between BAL and blood in terms of relative cytokine abundance and cytokine concentrations, regardless of HIV status, leading us to examine the effect of HIV on each compartment individually. In BAL of HIV-infected, ART-naïve 


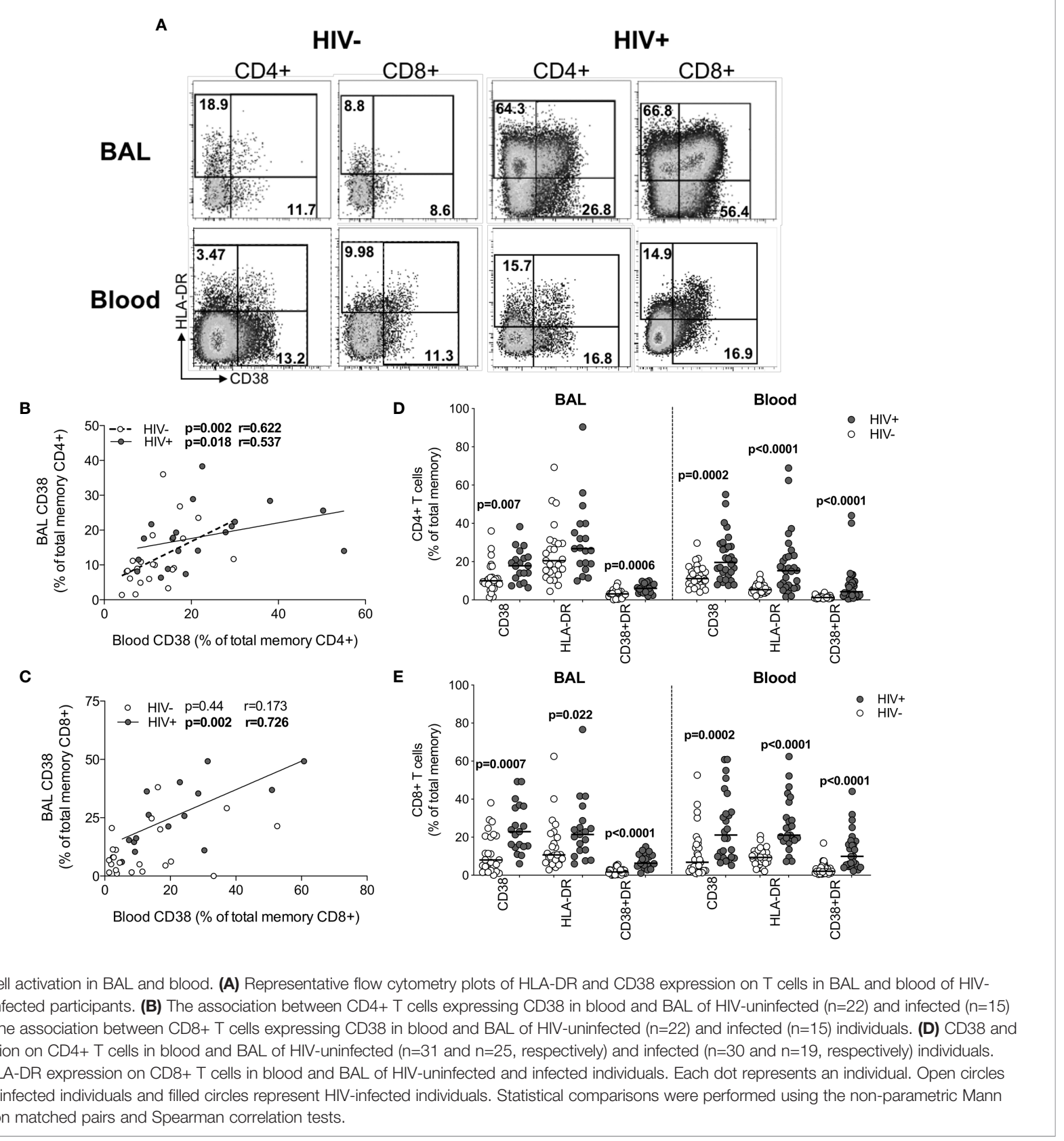

individuals, we detected a high viral load, and more $\mathrm{T}$ cells compared to HIV-uninfected individuals. HIV infection was also associated with increased frequencies of activated $\mathrm{T}$ cells. We observed a significant positive correlation between BAL viral load, absolute $\mathrm{T}$ cell numbers and the concentration of the chemokine CXCL10.

We detected high concentrations of HIV RNA in BAL fluid, consistent with earlier studies (19-21). The presence of HIV in the lung is likely to contribute to immunopathology and immune dysfunction, increasing susceptibility to respiratory diseases. We report a greater number of lymphocytes in HIV-infected airways, as has previously been described as lymphocytic alveolitis, thought to be predominantly made up of cytotoxic CD8+ T cells $(24,26,27,37)$. On its own, lymphocytic alveolitis causes limited pathology (25), but may contribute to the increased prevalence of pulmonary disease during HIV infection. COPD is associated with an increase in airway CD8+ T cells, particularly when combined with smoking or other risk factors (38-40). Lymphocytic alveolitis may also impair the normal response to pulmonary infections. A CD4+ T cell infiltration to the lungs would be expected in response to bacterial pathogens $(41,42)$, but this may be skewed towards CD8+ T cells during HIV infection. Indeed, TB-involved lung tissue from co-infected macaques (SIV and active TB) had fewer CD4+ T cells than 
A

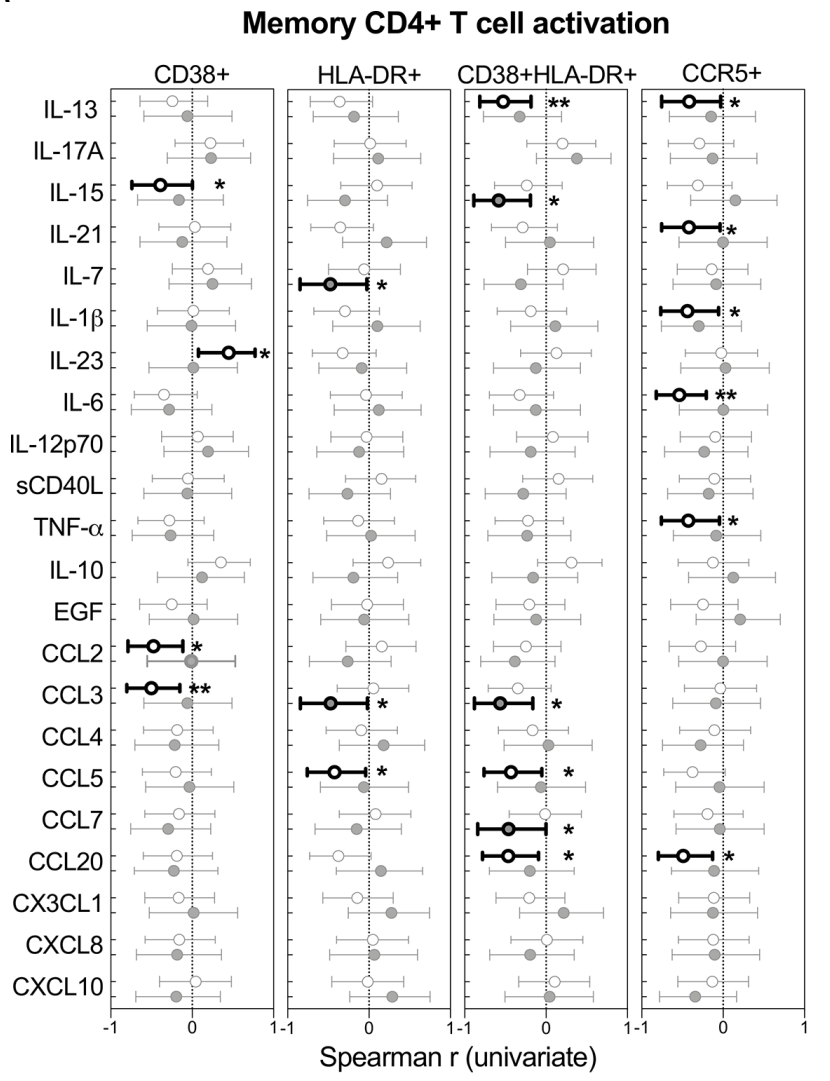

B

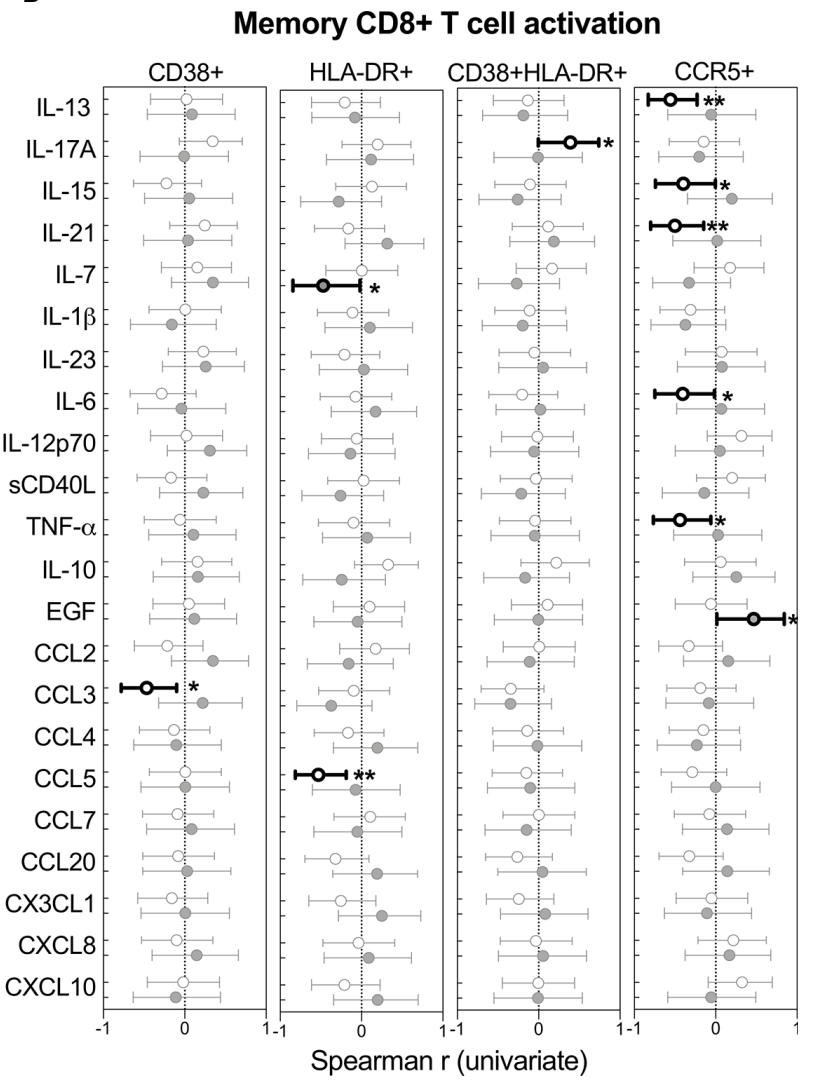

FIGURE 6 | Univariate associations between T cell activation markers and cytokine concentrations in BAL of HIV-infected ( $\mathrm{n}=14)$ and uninfected ( $\mathrm{n}=21$ ) individuals. Spearman rho $(r)$ of the univariate correlation between each cytokine and the expression of activation markers on (A) CD4+ T cells and (B) CD8+ T cells. Open circles represent HIV-uninfected individuals and filled circles represent HIV-infected individuals. Statistically significant correlations ( $\mathrm{p}<0.05)$ are indicated in darker lines and symbols. Spearman correlation tests, of which Spearman rho and the 95\% confidence intervals are reported here. None of the correlations remained statistically significant after adjusting for multiple comparisons by FDR step down procedures. The $p$ values, $p \leq 0.05, p \leq 0.01, p \leq 0.001, p \leq 0.0001$ are reported as ${ }^{*},{ }^{\star *},{ }^{\star \star \star}$ and ${ }^{\star \star \star \star}$, respectively.

those with active TB alone (43), suggesting SIV may interfere with the recruitment of $\mathrm{CD} 4+\mathrm{T}$ cells into involved tissue. Furthermore, the infiltration of activated, cytotoxic CD8+ T cells (37), together with local pathology caused by the HIV Nef protein, may also considerably compromise mucosal barrier function via endothelial dysfunction and increased epithelial permeability (44-48). In this study, HIV-infected individuals also had lower concentrations of EGF in BAL fluid. Together, our data and these studies suggest reduced mucosal barrier function and dysregulated migration of $\mathrm{T}$ cells, leading to suboptimal control of infection and disease.

In HIV-uninfected individuals, BAL CD4+ $\mathrm{T}$ cells were significantly more activated than in blood, which is consistent with a mucosal effector environment (49-51). HIV infection led to similar levels of activated CD4+ and CD8+ T cells in BAL and blood, the likely result of systemically activated cells migrating into the airways.

We found a clear compartmentalisation of cytokine profiles between blood and BAL, with more differences between compartments than between HIV-infected and uninfected individuals. This agrees strongly with a recent study reporting distinct transcriptional profiles between BAL cells and PBMC, regardless of HIV status (37), underscoring the assertion that blood may be a poor surrogate for immune processes in the airways. In BAL, CXCL10 was present at the highest relative proportion. CXCL10 is responsible for $\mathrm{T}$ cell chemoattraction and is upregulated in the healthy human lung during pulmonary infection and disease $(52,53)$. Indeed, the preservation and increase in the BAL $\mathrm{T}$ cell population may be driven by the local presence of chemokines, which are elevated during HIV infection $(19,54,55)$. We also found that the concentration of CXCL10 positively correlated with BAL viral load and BAL T cell numbers; and the latter two also associated with each other. These data suggest a relationship in which HIV may drive the expression of chemokines from lung cells, which in turn causes an infiltration of lymphocytes, including HIV-specific and M.tbspecific $\mathrm{T}$ cells $(17,18,29,56)$. We also observed elevated concentrations of the proinflammatory cytokines TNF- $\alpha$ and IFN- $\gamma$ in plasma, consistent with previous studies (10, 57-60). In contrast, we did not detect elevated proinflammatory cytokines in BAL, despite high viral loads. Excess inflammation in the lung 
may cause tissue damage, which may be especially detrimental to the integrity of alveoli, so an aggressive immune response that would be permissible elsewhere is thought to be tightly controlled and regulated in the lung (61). Indeed, studies have reported that BAL CD8+ T cells have lower cytotoxic potential compared to peripheral blood CD8+ T cells (62).

Although there may be continuous migration of virus between BAL and the circulation (63), local viral replication may also be occurring. HIV target cells in the lung include small alveolar macrophages and resident CD4+ T cells expressing CCR5 $(28,64)$. Thus, the lung may also act as a reservoir for HIV. Previous studies have shown distinct HIV env sequences isolated from the lung, compared to those isolated from peripheral blood in the same individual $(65,66)$. Whether the lung is an important viral reservoir in the context of viral suppression and cure needs further investigation.

Our study had several limitations. We were only able to phenotype BAL T cells on a limited number of participants, due to the challenge of obtaining sufficient cells from BAL. Although BAL is representative of the bronchus, it may not necessarily reflect the immune environment of lung tissue. Further studies examining lung biopsies or other sources of lung tissue during HIV infection would give a clearer picture of HIV-associated pulmonary dysfunction. Longitudinal studies, perhaps in nonhuman primate models, are required to fully understand the dynamics of the immune milieu over the course of HIV infection.

In conclusion, this study demonstrates that the immune environment of the airways is disrupted during HIV infection, with readily detectable virus and the accumulation of activated $\mathrm{T}$ lymphocytes that may be driven by high levels of chemokines such as CXCL10 at this site. Further mechanistic studies are required to determine whether HIV-associated changes in the airways contribute to the increased susceptibility to pulmonary disease during HIV infection.

\section{DATA AVAILABILITY STATEMENT}

The raw data supporting the conclusions of this article will be made available by the authors, without undue reservation.

\section{ETHICS STATEMENT}

The studies involving human participants were reviewed and approved by the Human Research Ethics Committee of the University of Cape Town (REF158/2010) and the Research

\section{REFERENCES}

1. UNAIDS. Fact Sheet HIV Statistics (2020). Available at: https://www.unaids. org/en/resources/fact-sheet.

2. Crothers K, Huang L, Goulet JL, Goetz MB, Brown ST, Rodriguez-Barradas $\mathrm{MC}$, et al. HIV Infection and Risk for Incident Pulmonary Diseases in the Combination Antiretroviral Therapy Era. Am J Respir Crit Care Med (2011) 183:388-95. doi: 10.1164/rccm.201006-0836OC
Ethics Committee of Stellenbosch University (N10/08/275). The patients/participants provided their written informed consent to participate in this study.

\section{AUTHOR CONTRIBUTIONS}

$\mathrm{WB}, \mathrm{RB}, \mathrm{AS}$, and RW conceived and designed the experiments. $\mathrm{RB}, \mathrm{AS}, \mathrm{NT}, \mathrm{TM}, \mathrm{AK}, \mathrm{ZG}$, and BC performed the experiments. $\mathrm{RB}, \mathrm{AS}, \mathrm{BM}, \mathrm{CR}$, and WB analyzed the data. FG-B, GW, DK, and RW contributed reagents, materials, and/or analysis tools. RB and WB wrote the manuscript. All authors contributed to the article and approved the submitted version.

\section{FUNDING}

This project is part of the EDCTP2 programme supported by the European Union (EU)'s Horizon 2020 programme (TMA2016SF-1535-CaTCH-22 to WB, TMA2017SF-1951-TBSpec to CR, TMA2020CDF-3187 to RB). Additional funding came from the Carnegie Corporation; the University of Cape Town; the Canada Africa Prevention Trials Network (all to RB); National Institutes of Health (grant R21AI115977 to CR); Wellcome Trust (203135 and 104803), NIH (U01 AI115940), the Francis Crick Institute (Cancer Research UK, MRC UK and Wellcome FC0010218), and SAMRC (SHIP) (all to RW).

\section{ACKNOWLEDGMENTS}

We thank the study participants, for providing samples and for their time and commitment to the study; the clinical staff at the Ubuntu HIV-TB clinic and the bronchoscopy suite at Tygerberg Academic Hospital, for providing essential support; Mrs Kathryn Norman, for administrative assistance; Maximilian L̈cke, for phlebotomy, cataloguing participant radiography findings, and database assistance.

\section{SUPPLEMENTARY MATERIAL}

The Supplementary Material for this article can be found online at: https://www.frontiersin.org/articles/10.3389/fimmu.2021. 707355/full\#supplementary-material

3. Meghji J, Miller RF. HIV and the Lung. Med (Baltimore) (2013) 41:435-41. doi: 10.1016/j.mpmed.2013.05.015

4. Drummond MB, Kirk GD, Astemborski J, Marshall MM, Mehta SH, McDyer JF, et al. Association Between Obstructive Lung Disease and Markers of HIV Infection in a High-Risk Cohort. Thorax (2012) 67:309-14. doi: 10.1136/ thoraxjnl-2011-200702

5. Louie JK, Chin Hsu L, Osmond DH, Katz MH, Schwarcz SK. Trends in Causes of Death Among Persons With Acquired Immunodeficiency 
Syndrome in the Era of Highly Active Antiretroviral Therapy, San Francisco, 1994-1998. J Infect Dis (2002) 186:1023-7. doi: 10.1086/343862

6. Sogaard OS, Lohse N, Gerstoft J, Kronborg G, Ostergaard L, Pedersen C, et al. Hospitalization for Pneumonia Among Individuals With and Without HIV Infection, 1995-2007: A Danish Population-Based, Nationwide Cohort Study. Clin Infect Dis (2008) 47:1345-53. doi: 10.1086/592692

7. Segal LN, Methé BA, Nolan A, Hoshino Y, Rom WN, Dawson R, et al. HIV-1 and Bacterial Pneumonia in the Era of Antiretroviral Therapy. Proc Am Thorac Soc (2011) 8:282-7. doi: 10.1513/pats.201006-044WR

8. Birx DL, Redfield RR, Tencer K, Fowler A, Burke DS, Tosato G. Induction of Interleukin-6 During Human Immunodeficiency Virus Infection. Blood (1990) 76:2303-10. doi: 10.1182/blood.V76.11.2303.bloodjournal76112303

9. Lahdevirta J, Maury CP, Teppo AM, Repo H. Elevated Levels of Circulating Cachectin/Tumor Necrosis Factor in Patients With Acquired Immunodeficiency Syndrome. Am J Med (1988) 85:289-91. doi: 10.1016/0002-9343(88)90576-1

10. Liovat A-S, Rey-Cuillé M-A, Lécuroux C, Jacquelin B, Girault I, Petitjean G, et al. Acute Plasma Biomarkers of T Cell Activation Set-Point Levels and of Disease Progression in HIV-1 Infection. PloS One (2012) 7:e46143. doi: 10.1371/journal.pone.0046143

11. Liu Z, Cumberland WG, Hultin LE, Kaplan AH, Detels R, Giorgi JV. CD8+ TLymphocyte Activation in HIV-1 Disease Reflects an Aspect of Pathogenesis Distinct From Viral Burden and Immunodeficiency. J Acquir Immune Defic Syndr Hum Retrovirol (1998) 18:332-40. doi: 10.1097/00042560-19980801000004

12. Giorgi JV, Liu Z, Hultin LE, Cumberland WG, Hennessey K, Detels R. Elevated Levels of CD38+ CD8+ T Cells in HIV Infection Add to the Prognostic Value of Low CD4+ T Cell Levels: Results of 6 Years of FollowUp. The Los Angeles Center, Multicenter AIDS Cohort Study. J Acquir Immune Defic Syndr (1993) 6:904-12.

13. Hazenberg MD, Otto SA, van Benthem BHB, Roos MTL, Coutinho RA, Lange JMA, et al. Persistent Immune Activation in HIV-1 Infection is Associated With Progression to AIDS. AIDS (2003) 17:1881-8. doi: 10.1097/00002030200309050-00006

14. Roberts L, Passmore JAS, Mlisana K, Williamson C, Little F, Bebell LM, et al. Genital Tract Inflammation During Early HIV-1 Infection Predicts Higher Plasma Viral Load Set Point in Women. J Infect Dis (2012) 205:194-203. doi: 10.1093/infdis/jir715

15. Gumbi PP, Jaumdally SZ, Salkinder AL, Burgers WA, Mkhize NN, Hanekom W, et al. CD4 T Cell Depletion at the Cervix During HIV Infection Is Associated With Accumulation of Terminally Differentiated T Cells. J Virol (2011) 85:13333-41. doi: 10.1128/JVI.05671-11

16. Brenchley JM, Douek DC. HIV Infection and the Gastrointestinal Immune System. Mucosal Immunol (2008) 1:23-30. doi: 10.1038/mi.2007.1

17. Jambo KC, Sepako E, Fullerton DG, Mzinza D, Glennie S, Wright AK, et al. Bronchoalveolar CD4+ T Cell Responses to Respiratory Antigens are Impaired in HIV-Infected Adults. Thorax (2011) 66:375-82. doi: 10.1136/ thx.2010.153825

18. Kalsdorf B, Scriba T, Wood K, Day CL, Dheda K, Dawson R, et al. HIV-1 Infection Impairs the Bronchoalveolar T-Cell Response to Mycobacteria. Am J Respir Crit Care Med (2009) 180:1262-70. doi: 10.1164/rccm.200907-1011OC

19. Kalsdorf B, Skolimowska KH, Scriba TJ, Dawson R, Dheda K, Wood K, et al. Relationship Between Chemokine Receptor Expression, Chemokine Levels and HIV-1 Replication in the Lungs of Persons Exposed to Mycobacterium Tuberculosis. Eur J Immunol (2013) 43:540-9. doi: 10.1002/eji.201242804

20. Twigg HLIII, Weiden M, Valentine F, Schnizlein-Bick CT, Bassett R, Zheng L, et al. Effect of Highly Active Antiretroviral Therapy on Viral Burden in the Lungs of HIV-Infected Subjects. J Infect Dis (2008) 197:109-16. doi: 10.1086/ 523766

21. Wood KL, Chaiyarit P, Day RB, Wang Y, Schnizlein-Bick CT, Gregory RL, et al. Measurements of HIV Viral Loads From Different Levels of the Respiratory Tract. Chest (2003) 124:536-42. doi: 10.1378/chest.124.2.536

22. Dean NC, Golden JA, Evans LA, Warnock ML, Addison TE, Hopewell PC, et al. Human Immunodeficiency Virus Recovery From Bronchoalveolar Lavage Fluid in Patients With AIDS. Chest (1988) 93:1176-9. doi: 10.1378/chest.93.6.1176

23. Linnemann CC, Baughman RP, Frame PT, Floyd R. Recovery of Human Immunodeficiency Virus and Detection of P24 Antigen in Bronchoalveolar Lavage Fluid From Adult Patients With AIDS. Chest (1989) 96:64-7. doi: 10.1378/chest.96.1.64
24. Agostini C, Poletti V, Zambello R, Trentin L, Siviero F, Spiga L, et al. Phenotypical and Functional Analysis of Bronchoalveolar Lavage Lymphocytes in Patients With HIV Infection. Am Rev Respir Dis (1988) 138:1609-15. doi: 10.1164/ajrccm/138.6.1609

25. Guillon JM, Autran B, Denis M, Fouret P, Plata F, Mayaud CM, et al. Human Immunodeficiency Virus-Related Lymphocytic Alveolitis. Chest (1988) 94:1264-70. doi: 10.1378/chest.94.6.1264

26. Twigg HLIII, Soliman DM, Day RB, Knox KS, Anderson RJ, Wilkes DS, et al. Lymphocytic Alveolitis, Bronchoalveolar Lavage Viral Load, and Outcome in Human Immunodeficiency Virus Infection. Am J Respir Crit Care Med (1999) 159:1439-44. doi: 10.1164/ajrccm.159.5.9808031

27. Young KR, Rankin JA, Naegel GP, Paul ES, Reynolds HY. Bronchoalveolar Lavage Cells and Proteins in Patients With the Acquired Immunodeficiency Syndrome. An Immunologic Analysis. Ann Intern Med (1985) 103:522-33. doi: 10.7326/0003-4819-103-4-522

28. Jambo KC, Banda DH, Kankwatira AM, Sukumar N, Allain TJ, Heyderman RS, et al. Small Alveolar Macrophages are Infected Preferentially by HIV and Exhibit Impaired Phagocytic Function. Mucosal Immunol (2014) 7:1116-26. doi: $10.1038 / \mathrm{mi} .2013 .127$

29. Bunjun R, Riou C, Soares AP, Thawer N, Müller TL, Kiravu A, et al. Effect of HIV on the Frequency and Number of Mycobacterium Tuberculosis-Specific CD4 + T Cells in Blood and Airways During Latent. M Tuberculosis Infect J Infect Dis (2017) 216:1550-60. doi: 10.1093/infdis/jix529

30. Rennard SI, Basset G, Lecossier D, O’Donnell KM, Pinkston P, Martin PG, et al. Estimation of Volume of Epithelial Lining Fluid Recovered by Lavage Using Urea as Marker of Dilution. J Appl Physiol (1986) 60:532-8. doi: 10.1152/jappl.1986.60.2.532

31. R: A Language and Environment for Statistical Computing (2020). Available at: www.R-project.org.

32. Kolde R. Pheatmap: Pretty Heatmaps. R Package Version 1012 (2019). Available at: https://cran.r-project.org/package=pheatmap.

33. Oksanen J, Blanchet FG, Friendly M, Kindt R, Legendre P, McGlinn D, et al. Vegan: Community Ecology Package. R Package Version 25-7 (2020). Available at: https://cran.r-project.org/package=vegan.

34. Tang Y, Horikoshi M , Li W. Ggfortify: Unified Interface to Visualise Statistical Result of Popular R Packages. R J (2016) 8:474.

35. Neuwirth E. RColorBrewer: ColorBrewer Palettes. $R$ Package Version 11-2 (2014). Available at: https://cran.r-project.org/package=RColorBrewer.

36. Columb MO, Sagadai S. Multiple Comparisons. Curr Anaesth Crit Care (2006) 17:233-6. doi: 10.1016/j.cacc.2006.03.005

37. Muema DM, Mthembu M, Schiff AE, Singh U, Corleis B, Chen D, et al. Contrasting Inflammatory Signatures in Peripheral Blood and Bronchoalveolar Cells Reveal Compartment-Specific Effects of HIV Infection. Front Immunol (2020) 11:1-13. doi: 10.3389/fimmu.2020.00864

38. Saetta M, Baraldo S, Corbino L, Turato G, Mapp CE, Maestrelli P, et al. CD8+ve Cells in the Lungs of Smokers With Chronic Obstructive Pulmonary Disease. Am J Crit Care Med (1999) 160:711-7. doi: 10.1164/ajrccm.160.2.9812020

39. Williams M, Todd I, Fairclough LC. The Role of CD8 + T Lymphocytes in Chronic Obstructive Pulmonary Disease: A Systematic Review. Inflamm Res (2021) 70:11-8. doi: 10.1007/s00011-020-01408-z

40. Di Stefano A, Caramori G, Ricciardolo FLM, Capelli A, Adcock IM, Donner CF. Cellular and Molecular Mechanisms in Chronic Obstructive Pulmonary Disease: An Overview. Clin Exp Allergy (2004) 34:1156-67. doi: 10.1111/ j.1365-2222.2004.02030.x

41. Hoheisel GB, Tabak L, Teschler H, Erkan F, Kroegel C, Costabel U. Patients With Pulmonary Tuberculosis. Am J Respir Crit Care Med (1994) 149:460-3. doi: 10.1164/ajrccm.149.2.8306046

42. Schwander SK, Sada E, Torres M, Escobedo D, Sierra JG, Alt S, et al. and Immature Macrophage Alveolitis in Active Pulmonary Tuberculosis. J Infect Dis (1996) 173:1267-72. doi: 10.1093/infdis/173.5.1267

43. Diedrich CR, Mattila JT, Klein E, Janssen C, Phuah J, Sturgeon TJ, et al. Reactivation of Latent Tuberculosis in Cynomolgus Macaques Infected With SIV is Associated With Early Peripheral T Cell Depletion and Not Virus Load. PloS One (2010) 5:e9611. doi: 10.1371/journal.pone.0009611

44. Almodovar S, Knight R, Allshouse AA, Roemer S, Lozupone C, McDonald D, et al. Human Immunodeficiency Virus Nef Signature Sequences are Associated With Pulmonary Hypertension. AIDS Res Hum Retroviruses (2012) 28:607-18. doi: 10.1089/aid.2011.0021 
45. Meignan M, Guillon JM, Denis M, Joly P, Rosso J, Carette MF, et al. Increased Lung Epithelial Permeability in HIV-Infected Patients With Isolated Cytotoxic T-Lymphocytic Alveolitis. Am Rev Respir Dis (1990) 141:1241-8. doi: 10.1164/ajrccm/141.5_Pt_1.1241

46. Marecki JC, Cool CD, Parr JE, Beckey VE, Luciw PA, Tarantal AF, et al. HIV-1 Nef is Associated With Complex Pulmonary Vascular Lesions in SHIV-NefInfected Macaques. Am J Respir Crit Care Med (2006) 174:437-45. doi: 10.1164/rccm.200601-005OC

47. Borchers MT, Wesselkamper SC, Curull V, Ramirez-Sarmiento A, SánchezFont A, Garcia-Aymerich J, et al. Sustained CTL Activation by Murine Pulmonary Epithelial Cells Promotes the Development of COPD-Like Disease. J Clin Invest (2009) 119:636-49. doi: 10.1172/JCI34462

48. Small BA, Dressel SA, Lawrence CW, Drake DR, Stoler MH, Enelow RI, et al. CD8(+) T Cell-Mediated Injury. Vivo Progresses Absence Effector T Cells J Exp Med (2001) 194:1835-46. doi: 10.1084/jem.194.12.1835

49. Galkina E, Thatte J, Dabak V, Williams MB, Ley K, Braciale TJ. Preferential Migration of Effector CD8+ T Cells Into the Interstitium of the Normal Lung. J Clin Invest (2005) 115:3473-83. doi: 10.1172/JCI24482

50. Kohlmeier JE, Miller SC, Woodland DL. Cutting Edge: Antigen Is Not Required for the Activation and Maintenance of Virus-Specific Memory CD8 + T Cells in the Lung Airways. J Immunol (2007) 178:4721-5. doi: 10.4049/jimmunol.178.8.4721

51. Woodland DL. T Cell Memory in the Lung Airways. Proc Am Thorac Soc (2005) 2:126-31. doi: 10.1513/pats.200501-003AW

52. Spurrell JCL, Wiehler S, Zaheer RS, Sanders SP, Proud D. Human Airway Epithelial Cells Produce IP-10 (CXCL10) In Vitro and In Vivo Upon Rhinovirus Infections. Am J Physiol Lung Cell Mol Physiol (2005) 289:L8595. doi: 10.1152/ajplung.00397.2004

53. Jiang D, Liang J, Guo R, Xie T, Kelly FL, Martinu T, et al. Long-Term Exposure of Chemokine CXCL10 Causes Bronchiolitis-Like Inflammation. Am J Respir Cell Mol Biol (2012) 46:592-8. doi: 10.1165/rcmb.2011-0116OC

54. Brenchley JM, Paiardini M, Knox KS, Asher AI, Cervasi B, Asher TE, et al. Differential Th17 CD4 T-Cell Depletion in Pathogenic and Nonpathogenic Lentiviral Infections. Blood (2008) 112:2826-35. doi: 10.1182/blood-2008-05-159301

55. Denis M, Ghadirian E. Alveolar Macrophages From Subjects Infected With HIV-1 Express Macrophage Inflammatory Protein-1 Alpha (MIP-1 Alpha): Contribution to the CD8+ Alveolitis. Clin Exp Immunol (1994) 96:187-92. doi: 10.1111/j.1365-2249.1994.tb06540.x

56. Neff CP, Chain JL, MaWhinney S, Martin AK, Linderman DJ, Flores SC, et al. Lymphocytic Alveolitis Is Associated With the Accumulation of Functionally Impaired HIV-Specific T Cells in the Lung of Antiretroviral Therapy-Naive Subjects. Am J Respir Crit Care Med (2015) 191:464-73. doi: 10.1164/ rccm.201408-1521OC

57. Norris PJ, Pappalardo BL, Custer B, Hecht FM, Busch MP. Elevations in IL10 , TNF- $\alpha$, and IFN- $\gamma$ From the Earliest Point of HIV Type 1 Infection. AIDS Res Hum Retroviruses (2008) 22:757-62. doi: 10.1089/aid.2006.22.757

58. Roberts L, Passmore JS, Williamson C, Bebell LM, Mlisana K, Burgers WA, et al. Plasma Cytokine Levels During Acute HIV-1 Infection Predict HIV
Disease Progression. Aids (2010) 24:819-31. doi: 10.1097/QAD. 0b013e3283367836

59. Stacey AR, Norris PJ, Qin L, Haygreen EA, Taylor E, Heitman J, et al. Induction of a Striking Systemic Cytokine Cascade Prior to Peak Viremia in Acute Human Immunodeficiency Virus Type 1 Infection, in Contrast to More Modest and Delayed Responses in Acute Hepatitis B and C Virus Infections. J Virol (2009) 83:3719-33. doi: 10.1128/JVI.01844-08

60. Wada NI, Jacobson LP, Margolick JB, Breen EC, Macatangay B, Penugonda S, et al. The Effect of HAART-Induced HIV Suppression on Circulating Markers of Inflammation and Immune Activation. AIDS (2015) 29:463-71. doi: 10.1097/QAD.0000000000000545

61. Chen K, Kolls JK. T Cell-Mediated Host Immune Defenses in the Lung. Annu Rev Immunol (2013) 31:605-33. doi: 10.1146/annurev-immunol-032712100019

62. Meziane O, Alexandrova Y, Olivenstein R, Dupuy FP, Salahuddin S, Thomson E, et al. Peculiar Phenotypic and Cytotoxic Features of Pulmonary Mucosal CD8 T Cells in People Living With HIV Receiving Long-Term Antiretroviral Therapy. J Immunol (2021) 3:641-51. doi: 10.4049/jimmunol.2000916

63. Heath L, Fox A, McClure J, Diem K, van Wout AB, Zhao H, et al. Evidence for Limited Genetic Compartmentalization of HIV-1 Between Lung and Blood. PloS One (2009) 4:e6949. doi: 10.1371/journal.pone.0006949

64. Corleis B, Bucsan AN, Deruaz M, Vrbanac VD, Lisanti-Park AC, Gates SJ, et al. HIV-1 and SIV Infection Are Associated With Early Loss of Lung Interstitial CD4+ T Cells and Dissemination of Pulmonary Tuberculosis. Cell Rep (2019) 26:1409-18. doi: 10.1016/j.celrep.2019.01.021

65. Nakata K, Weiden M, Harkin T, Ho D, Rom WN. Low Copy Number and Limited Variability of Proviral DNA in Alveolar Macrophages From HIV-1Infected Patients: Evidence for Genetic Differences in HIV-1 Between Lung and Blood Macrophage Populations. Mol Med (1995) 1:744-57. doi: 10.1007/ BF03401889

66. Itescu S, Simonelli PF, Winchester RJ, Ginsberg HS. Human Immunodeficiency Virus Type 1 Strains in the Lungs of Infected Individuals Evolve Independently From Those in Peripheral Blood and are Highly Conserved in the C-Terminal Region of the Envelope V3 Loop. Proc Natl Acad Sci U S A (1994) 91:11378-82. doi: 10.1073/pnas.91.24.11378

Conflict of Interest: The authors declare that the research was conducted in the absence of any commercial or financial relationships that could be construed as a potential conflict of interest.

Copyright (c) 2021 Bunjun, Soares, Thawer, Müller, Kiravu, Ginbot, Corleis, Murugan, Kwon, von Groote-Bidlingmaier, Riou, Wilkinson, Walzl and Burgers. This is an open-access article distributed under the terms of the Creative Commons Attribution License (CC BY). The use, distribution or reproduction in other forums is permitted, provided the original author(s) and the copyright owner(s) are credited and that the original publication in this journal is cited, in accordance with accepted academic practice. No use, distribution or reproduction is permitted which does not comply with these terms. 